\title{
Expression of somatostatin and its receptor 1-5 in endometriotic tissues and cells
}

\author{
YANHUA ZHAO ${ }^{1}, \mathrm{LIN} \mathrm{PENG}^{2}, \mathrm{XIANG} \mathrm{LI}^{3}$ and YI ZHANG ${ }^{1}$ \\ ${ }^{1}$ Department of Obstetrics and Gynecology; ${ }^{2}$ Reproductive and Stem Cell Research Institute; \\ ${ }^{3}$ Department of Pathology, Xiangya Hospital of Central South University, Changsha, Hunan 410008, P.R. China
}

Received December 18, 2015; Accepted March 9, 2018

DOI: $10.3892 /$ etm.2018.6730

\begin{abstract}
The present study aimed to detect the expression of somatostatin (SS) and SS receptor (SSTR)1-5 in tissues from patients with endometriosis (EMS). Reverse transcription-quantitative polymerase chain reaction analysis was applied to examine the expression of somatostatin gene in ectopic endometrial cells (EECs). The expression of somatostatin receptor 1-5 in the ectopic endometrium (EE), eutopic endometrium and normal endometrium and their association with EMS staging were determined by immunohistochemistry. The results indicated that the expression of SS in EECs was significantly higher compared with that in the control group. SSTR1-5 were expressed in the EE tissues from 30 patients with EMS, and the positive rates were 43.3, 70.0, 53.3, 50.0 and $96.7 \%$, respectively, which were closely associated with EMS staging of the patients. The positive rates of SSTR1-5 expression in the eutopic endometrium from 12 patients with EMS were $33.3,41.7,58.3,58.3$ and $83.3 \%$, respectively, while the positive rates of SSTR1-5 expression in the normal endometrium from 14 women without EMS were 7.1, 7.1, 21.4, 28.6 and 64.3\%, which were lower than the positive rates of SSTR1-5 in the EE $(43.3,70,53.3,50$ and $96.7 \%)$ and eutopic endometrial cells (33.3, 41.7, 58.3, 58.3 and 83.3\%). In conclusion, SS was highly expressed in EECs. SSTR1-5 were expressed in the ectopic as well as eutopic endometrium, and low or moderate expression of SSTR1-4 and high expression of SSTR5 were detected in the ectopic and eutopic endometrial tissues, while low expression of SSTR1-4 and partial expression of SSTR5 were detected in normal endometrium. The positive rates of expression of SSTR1-5 in the EE cells and eutopic endometrium were higher than those in the normal endometrium. The expression of all the subtypes of SSTR in the EE tissues was closely associated with EMS staging.
\end{abstract}

Correspondence to: Dr Yi Zhang, Department of Obstetrics and Gynecology, Xiangya Hospital of Central South University, 87 Xiangya Road, Changsha, Hunan 410008, P.R. China

E-mail: zhangyi_zh2015@sina.com

Key words: somatostatin, somatostatin receptor, ectopic endometriotic tissues

\section{Introduction}

The incidence of endometriosis (EMS) has increased in recent years, and has become one of the most common gynecological diseases affecting numerous women at childbearing age (1). The present treatment method for EMS mainly includes hormone therapy and surgery since the efficacy of drug treatment is not ideal and the disease easily recurs (2). Somatostatin (SS) is a peptide hormone with extensive physiological effects. It is a natural polypeptide hormone containing 14 or 28 amino acids, which widely occurs in human endocrine and exocrine systems, and has extensive biological effects, which are mainly inhibitory (3). SS and its analogues have been used to treat neurological diseases, including Alzheimer's disease, chorea and epilepsy, tumor types, including pituitary, pancreatic islet cell and carcinoid tumor; and certain gastrointestinal diseases, including gastric ulcer, stomach bleeding and digestive tract ulcer, acute pancreatitis and bleeding from esophageal varices (4-6). The physiological functions of SS include hormone regulation, inhibition of cell proliferation, neurotransmitter release, inhibition of gastric acid, secretion of pepsin and gastrin, reduction of splanchnic blood flow, as well as the inhibition of the release of insulin-like growth factor (IGF)-1, platelet-derived growth factor, epidermal growth factor, white blood cell interleukin (IL)-6 and interferon (IFN)- $\gamma(4,7)$.

Numerous studies have indicated that SS inhibits the proliferation of tumor cells $(8,9)$. It acts by binding to specific cell surface receptors, SS receptors (SSTRs), which occurs as 5 SSTR subtypes named as SSTR1-5 (10). SSTR exists in a wide variety of neuroendocrine tumors and tumors of the nervous system (11). Certain studies have reported the expression of SSTR in endometrial and ovarian cancer $(12,13)$. However, few studies have focused on the expression of SSTR in EMS lesions. The present study was designed to detect the expression of the SS and SSTR1-5 genes in EMS tissue and its association with the disease.

\section{Materials and methods}

Tissue samples. The EMS tissues and cells were extracted from 30 female patients during gynecological laparotomy or laparoscopic surgeries at the Department of Obstetrics and Gynecology, Xiangya Hospital of Central South University (Changsha, China) between July 2009 and December 2012. 
The specimens included cystic walls from 28 cases with ovarian chocolate cyst and samples from 2 patients with pelvic peritoneal EMS. Specimens were confirmed by the Department of Pathology of Central South University, fixed with $10 \%$ formalin and embedded in common paraffin. The patients had no particular disease history, had not received any hormone therapy pre-operatively within 3 months, and were aged between 20 and 45 years (mean age, 35.68 years). The patients were staged in line with the Revised American Fertility Society I system (14): 2 Patients were stage I, 7 cases were stage II, 16 cases were stage III and 5 cases were stage IV. The eutopic endometrium was derived from 12 additional EMS patients undergoing gynecologic abdominal hysterectomy or uterine laparoscopy between July 2009 and December 2012 in the Department of Obstetrics and Gynecology of Xiangya Hospital of Central South University, all samples were endometrium at the proliferative phase, and the average age of the donors was 40.52 years. A total of 14 specimens for the control group were collected from cervical intraepithelial neoplasia (CIN) patients undergoing surgical resection with normal endometrium between July 2009 and December 2012 in the Department of Obstetrics and Gynecology of Xiangya Hospital of Central South University, all samples were endometrium at the proliferative phase, the age of the patients was $40-48$ years, and their average age was 45.18 years. The present study was approved by Ethics Committee of Xiangya Hospital of Central South University and informed consent was obtained from all subjects.

Cell sources. Normal endometrium (NE) cells were obtained from 15 healthy females of childbearing age undergoing curettage at the outpatient department of Xiangya Hospital of Central South University between September 2012 and April 2013. The ectopic endometrial (EE) cells were obtained from 15 hospitalized patients undergoing ovarian EMS cyst or laparoscopic surgery at the same time. The specimens were collected from a $0.5-1 \mathrm{~mm}$-thick portion in the inner cystic walls from ovarian chocolate cysts. The mean age in the two groups was $30.25 \pm 4.35$ and $32.05 \pm 5.29$ years, respectively $(\mathrm{P}>0.05)$. None of the patients had any tumors or any endocrine, immune or metabolic diseases and no hormonal drugs had been administered within 3 months. No pathological change was found in the NE group on histological examination. The histological staging was consistent with the actual menstrual cycle, and ovarian EMS cyst was diagnosed in EE cell group.

Reagents. Primary antibodies against SSTR1 (cat. no. BA1405; 1:100) and SSTR3 (cat. no. BA1407; 1:100) were purchased from (Wuhan Boster Biological Technology, Co., Ltd., Wuhan, China). Primary antibodies of SSTR2 (cat. no. ab134152; 1:100), SSTR4 (cat. no. ab28578; 1:2,500) and SSTR5 (cat. no. ab109495; 1:100) were purchased from Abcam (Cambridge, MA, USA). Dulbecco's modified Eagle's medium (DMEM)/F12 was purchased from Beijing Dingguo Biotechnology Co., Ltd (Beijing, China), fetal bovine serum was purchased from Shanghai Sijiqing Co., Ltd (Shanghai, China) and collagenase IV and trypsin were purchased from Sigma-Aldrich (Merck KGaA, Darmstadt, Germany).
Cell separation and culture. To establish in vitro cultures, the method reported previously was used $(4,7)$, with certain modifications: The obtained tissues were washed three times with PBS, dissected it into $0.5-1 \mathrm{~mm}^{3}$ pieces and placed in a $20-\mathrm{ml}$ centrifugal tube. Following addition of 2.5-5.0 volumes of $0.1 \%$ collagenase and $0.25 \%$ trypsin digestion solution and even mixing, the samples were incubated in a water bath at $37^{\circ} \mathrm{C}$ with continuous agitation for 50-100 $\mathrm{min}$ in NE group and 80-120 min in the EE group. Subsequently, DMEM was added to stop the digestion, followed by repeated pipetting of the samples. The cells were then filtered through a 100-mesh stainless steel net. The filtrate, mainly containing the mesenchymal and epithelial cells, was centrifuged at $170 \mathrm{xg}$ for $10 \mathrm{~min}$, the supernatant was removed, and the pellet was resuspended in DMEM/F12 with $15 \%$ fetal bovine serum, and after the cell count was determined under trypan blue staining, the cell concentration in the suspension was adjusted to $5 \times 10^{5}$ cells $/ \mathrm{ml}$. The cells were inoculated into a culture dish and cultured in an incubator with $5 \% \mathrm{CO}_{2}$ at $37^{\circ} \mathrm{C}$ with the medium replaced once every 2-3 days until cell convergence was reached in the primary culture. The cell shapes and growth were observed with an inverted microscope and images were captured.

Reverse transcription-quantitative polymerase chain reaction $(R T-q P C R)$. The PCR primers were designed based on the human SS mRNA sequences from GenBank, and GAPDH was used as a control. The primers were synthesized by Nanjing GenScript Biotechnical Co., Ltd (Nanjing, China) and had the following sequences (in 5'-3' direction): SS upstream, GCTGCTGTCTGAACCC and downstream, CGTTCTCGG GGTGCCATAG (product length, 138 bp); GAPDH upstream, TGCACCACCAACTGC and downstream, GGCATGGAC TGTGGTCATGAG (product length, $87 \mathrm{bp}$ ). Total RNA was extracted using TRIZOL reagent (Invitrogen; Thermo Fisher Scientific, Inc., Waltham, MA, USA) according to the manufacturer's protocol. A cDNA Reverse Transcription lit (Applied Biosystems; Thermo Fisher Scientific, Inc.) was used for reverse transcription. Briefly, $3 \mu \mathrm{g}$ total RNA $(0.5 \mu \mathrm{g} / \mu \mathrm{l}), 1 \mu \mathrm{l}$ Oligo dT Primer, $1 \mu \mathrm{l}$ dNTP Mixture (both Takara Biotechnology Co., Ltd., Dalian, China) and RNase-free doubly distilled (dd) $\mathrm{H}_{2} \mathrm{O}$ (Beijing Solarbio Science \& Technology Co., Ltd., Beijing, China) were mixed with the total mixture of $10 \mu 1$. The mixture was stirred at $70^{\circ} \mathrm{C}$ for $5 \mathrm{~min}$ and then the $10 \mu \mathrm{l}$ mixture, $4 \mu 15 \mathrm{X}$ PrimeScript II Buffer, $0.5 \mu 1$ RNase inhibitor, $1 \mu \mathrm{l}$ PrimeScript II RTase and $4.5 \mu \mathrm{l}$ RNase-free $\mathrm{ddH}_{2} \mathrm{O}$ were mixed followed by a reaction at $45^{\circ} \mathrm{C}$ for $45 \mathrm{~min}$ and $95^{\circ} \mathrm{C}$ for 5 min. PCR was performed on a Mastercycler ${ }^{\circledR}$ RealPlex $^{2}$ thermal cycler (Eppendorf, Hamburg, Germany) and data were analyzed by MxPro software (version 4.0; (Stratagene; Agilent Technologies, Inc., Santa Clara, CA, USA). The reaction system $(18 \mu \mathrm{l})$ comprised diethyl pyrocarbonate-treated $\mathrm{H}_{2} \mathrm{O}$ (3.6 $\mu \mathrm{l}), 1.2 \mu \mathrm{l}$ of a $10-\mu \mathrm{M}$ solution of each primer, $10 \mu \mathrm{l} \mathrm{SYBR}^{\circledR}$ Green Realtime PCR Master Mix and $2 \mu \mathrm{l}$ complementary DNA. Each condition was performed in 3 parallel wells. The following thermocycling program was used: $95^{\circ} \mathrm{C}$ for $10 \mathrm{~min}$, followed by 42 cycles of $95^{\circ} \mathrm{C}$ for $30 \mathrm{sec}$ and $58^{\circ} \mathrm{C}$ for $20 \mathrm{sec}$, and $72^{\circ} \mathrm{C}$ for $30 \mathrm{sec}$. Following determination of the $\Delta \mathrm{Cq}$ value, the relative expression level of the target mRNA was calculated. Using GAPDH as an internal reference, the relative changes in gene expression were calculated as $2^{-\Delta \Delta C q}(15)$. 
Immunohistochemical method. Samples were prepared according to the protocol of immunohistochemical staining kit (SA1098; Wuhan Boster Biological Technology, Co., Ltd.) using the streptavidin-biotin complex approach. A negative control was prepared by using PBS instead of primary antibody and normal endometrial tissues sections were used as positive controls. Following incubation, DAB regent (AR1025; Wuhan Boster Biological Technology, Co., Ltd.) was used for further staining; samples were incubated with DAB reagent at room temperature for $5 \mathrm{~min}$. The film was read by blinded observers under a light microscope. Yellow or brown staining indicated positive results. Brown or yellow granules indicating SSTR staining were mainly localized in the cytoplasm, and the expression of SSTR was determined by using a quantitative method. The scores were summed up based on the coloring depth and the positive cell numbers, where 0 indicated positive staining, 1 light brown staining, 2 dark brown staining and 3 tan staining. A total of 10 high-magnification fields of view were counted per sample to determine the positive rates and the average was determined. The score(s) for the proportion of cells with positive staining were as follows: $0,<5 \% ; 1,5-24 \%$; $2,25-49 \% ; 3,50-74 \%$ and $4, \geq 75 \%$. The scores for staining intensity and proportion of stained cells were multiplied and patients with a score of $<1$ were considered as negative, while the remaining patients were considered as positive. A score of 1-3 indicated weakly positive (+), 4 and 5 indicated positive (+) and $\geq 6$ indicated highly positive $(++)$ staining.

Statistical methods. Values are expressed as the mean \pm standard deviation. Comparison between two groups was performed using Student's t-test. Comparison of rates was performed using the Chi-square test. $\mathrm{P}<0.05$ was considered to indicate a statistically significant difference. All calculations were performed using SPSS 19.0 (IBM Corp., Armonk, NY, USA).

\section{Results}

Expression of SS mRNA in the different groups. The relative expression of SS mRNA in the cells of the EE and NE groups was automatically output by MxPro software (Fig. 1). Results demonstrated that the expression of SS was significantly higher in the EE group compared with that in the NE group $(\mathrm{P}<0.05)$.

Expression of SSTR subtypes in EMS tissues. Immunohistochemical analysis revealed that in ectopic endometrial cells, SSTR was mostly located in the cytoplasm and cell membrane. Among the 30 cases of EMS, expression of SSTR1 was present in EMS cells of 13 patients (43.3\%), SSTR2 in those of 21 patients (70\%), SSTR3 in $16(53.5 \%)$, SSTR4 in $15(50 \%)$ and SSTR5 was expressed in EMS cells of 29 patients (96.7\%; Fig. 2 and Table I). Compared with the positive expression rate in the control group (the NS cells), the expression rate of SSTR1, SSTR2, SSTR3 and SSTR5 was significantly increased in the EMS group $(\mathrm{P}<0.05$; Table II). In EMS tissue, the expression of SSTR subtypes and the clinical stage were significantly associated $(\mathrm{P}<0.001$; Table I).

Expression of SSTR subtypes in eutopic and ectopic endometrial tissues in the EMS and normal control group. The positive expression rates of SSTR1-5 in eutopic

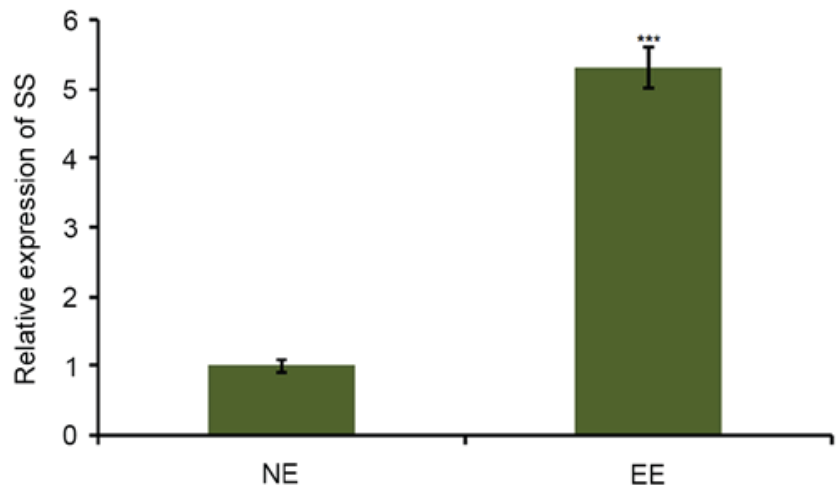

Figure 1. Expression of somatostatin gene in cells of EE and NE groups. ${ }^{* * *} \mathrm{P}<0.001$, compared with the NE group. EE, ectopic endometrium; $\mathrm{NE}$, normal endometrium.
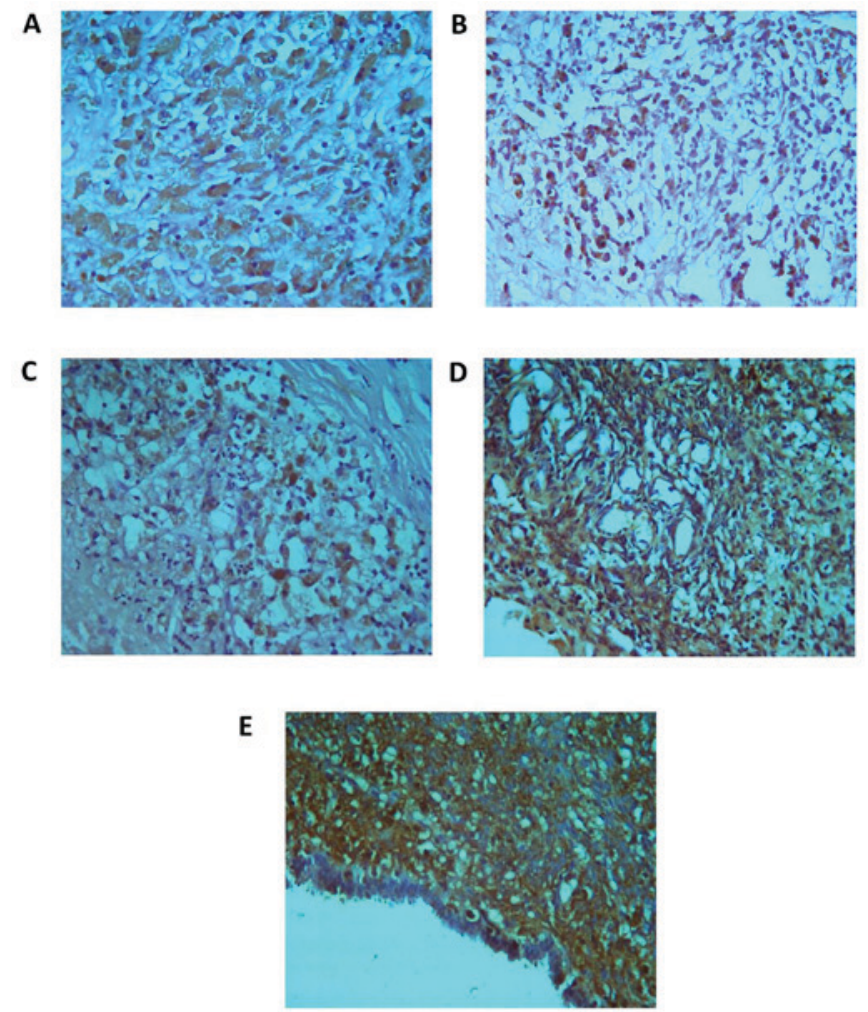

Figure 2. Immunohistochemical staining for SSTR subtypes in endometriotic tissues (magnification, x400). (A) SSTR1, (B) SSTR2, (C) SSTR3, (D) SSTR4 and (E) SSTR5. SSTR, somatostatin receptor.

endometrium from 12 cases were 33.3, 41.7, 58.3, 58.3 and $83.3 \%$ (Fig. 3 and Table II), and the positive expression rates of SSTR1-5 were all significantly higher compared with the control group $(\mathrm{P}<0.05)$. The positive expression rates of SSTR1-5 in normal endometrium (7.1, 7.1, 21.4, 28.6 and $64.3 \%$ ) were lower compared with those in the ectopic $(43.3,70.0,53.3,50.0$ and $96.7 \%)$ and eutopic endometrium (33.3, 41.7, 58.3, 58.3 and 83.3\%) groups (Fig. 4; Table II).

\section{Discussion}

SS is a natural polypeptide that is extensively distributed in the digestive and nervous system, and exhibits several biological 
Table I. Positive rate of expression of SSTR subtypes in endometriotic tissues and its association with clinical staging.

\begin{tabular}{|c|c|c|c|c|c|c|}
\hline \multirow[b]{2}{*}{ Expression status/rate } & \multirow[b]{2}{*}{$\mathrm{N}(\%)$} & \multicolumn{4}{|c|}{ Clinical stage, n (\%) } & \multirow[b]{2}{*}{ P-value } \\
\hline & & I & II & III & IV & \\
\hline \multicolumn{7}{|l|}{ SSTR1 } \\
\hline Positive & $13(43.3)$ & $0(0)$ & $2(15.38)$ & $7(53.85)$ & $4(30.77)$ & $<0.001$ \\
\hline Negative & 17 & $1(5.88)$ & $5(29.41)$ & $10(58.82)$ & $1(5.88)$ & \\
\hline \multicolumn{7}{|l|}{ SSTR2 } \\
\hline Positive & $21(70)$ & $0(0)$ & $5(23.81)$ & $11(52.38)$ & $5(23.81)$ & $<0.001$ \\
\hline Negative & 9 & $1(11.11)$ & $2(22.22)$ & $7(77.77)$ & $0(0)$ & \\
\hline \multicolumn{7}{|l|}{ SSTR3 } \\
\hline Positive & $16(53.3)$ & $1(6.25)$ & $3(18.75)$ & $3(18.75)$ & $9(56.25)$ & $<0.001$ \\
\hline Negative & 14 & $1(7.14)$ & $4(28.57)$ & $7(50.00)$ & $2(14.29)$ & \\
\hline \multicolumn{7}{|l|}{ SSTR4 } \\
\hline Positive & $15(50.0)$ & $0(0)$ & $1(6.67)$ & $10(66.67)$ & $4(26.67)$ & $<0.001$ \\
\hline Negative & 15 & $2(13.33)$ & $6(40.00)$ & $6(40.00)$ & $1(6.67)$ & \\
\hline \multicolumn{7}{|l|}{ SSTR5 } \\
\hline Positive & $29(96.7)$ & $2(6.90)$ & $6(20.69)$ & $16(55.17)$ & $5(17.24)$ & $<0.001$ \\
\hline Negative & 1 & $0(0)$ & $1(100.00)$ & $0(0)$ & $0(0)$ & \\
\hline
\end{tabular}

SSTR, somatostatin receptor.

effects (16). The clinical application of SS is restricted, as natural SS has a short half-life in vivo of 4 min only (17). The SS analogue (SSTA) has the advantages of a long half-life, relatively long-lasting effect, high selectivity and ease of application (18). Numerous types of cancer cell, inflammatory cell and immune cell (e.g., lymphocytes, phagocytic cells, endothelial cells and thymus cells) also produce SS (19). Growth hormones IGF, IL-1, IL- 6 , TNF- $\alpha$ and IFN- $\gamma$, and other growth factors and cytokines as well as glucocorticoid, androgen and estrogen may increase the expression of SS, whilst insulin and leptin may inhibit its expression $(4,7)$. The intracellular factors regulating the expression of SS mainly include cyclic adenosine monophosphate (AMP), $\mathrm{Ca}^{2+}$, cyclic guanine monophosphate and nitric oxide (19). cAMP has a promoting effect on the expression and secretion of the SS gene, which resembles a signal transduction pathway to regulate the function of SS (19).

The RT-qPCR results of the present study indicated that the expression of SS mRNA in EMS cells was significantly higher compared with the normal endometrial cells. Sbracia and Scarpellini (20) demonstrated that the occurrence of EMS is associated with immune mechanisms. The activity of intraperitoneal mononuclear macrophages in EMS patients is increased, and they secrete large amounts of inflammatory mediators, including IL-1, IL- 6 and TNF- $\alpha$, which creates an environment that drives EMS cell proliferation (21). These factors also promote the expression of the SS gene (22). The present study indicated that the expression of the SS gene is elevated in EMS cells, and this increase is likely to be associated with the occurrence and development of the disease.

Numerous studies have indicated that SS is an important hormone regulatory peptide that restrains cell proliferation and differentiation, and which may be utilized to inhibit the proliferation and angiogenesis of tumor cells (23). The mechanism underlying the inhibitory effect of SS mainly includes direct inhibition and also indirect effects (24). After binding and activation, SS, SSTA and SSTR may exert anti-proliferative effects through 4 major signaling pathways (4): i) Via the cAMP pathway to change cAMP metabolism. The decrease in cAMP leads to inhibition of cell proliferation and affects protein synthesis (19); ii) changes in intracellular $\mathrm{Ca}^{2+}$ to reduce the membrane permeability regarding $\mathrm{Ca}^{2+}$, inhibit $\mathrm{Ca}^{2+}$ influx and block $\mathrm{Ca}^{2+}$-mediated intracellular processes (6); iii) phosphate protein kinase pathways: After the SSTR binds to ligands, tyrosine kinase is inactivated by dephosphorylation to inhibit protein kinases, e.g., mitogen-activated protein kinase (MAPK), leading to inhibition of cell proliferation $(25,26)$; iv) the phosphatidylinositol-3-kinase (PI3K) pathway: SSTA inhibits the proliferation of tumor cells through the inhibition of PI3K (27). The indirect inhibitory effects of SSTA comprise activation of Fas, Caspase- 8 and MAPK pathways mediated via receptors, blocking cell cycle progression from G1 phase to $S$ phase, inhibition of the cell proliferation and promotion of apoptosis $(28,29)$. A further indirect inhibitory effect of SSTA is the inhibition of angiogenesis $(30,31)$. The ectopic endometrium as autografts rather relies on vascular support, and angiogenesis is crucial to the development of EMS (32), and thus the occurrence and development of EMS may be inhibited through the above mechanisms by using SSTA, which requires to be further verified.

SS acts through binding to specific receptors on the cell surface and SSTR is a membrane protein receptor, which is divided into 5 subtypes and has 7 transmembrane domains (10). According to the similarity and varying affinity towards SSTR, SS may be divided two types: i) High affinity to SSTR, 
Table II. Expression of SSTR subtypes in endometrial tissues of ectopic $(n=30)$, eutopic $(n=12)$ and control endometrium $(n=14)$ groups.

Immunohistochemical staining (n)

\begin{tabular}{|c|c|c|c|c|c|c|}
\hline \multirow[b]{2}{*}{ Group/subtype } & & & & & \multirow[b]{2}{*}{ Positive rate (\%) } & \multirow[b]{2}{*}{ P-value ${ }^{a}$} \\
\hline & - & +- & + & ++ & & \\
\hline \multicolumn{7}{|l|}{ Control } \\
\hline SSTR1 & 13 & 1 & 0 & 0 & 7.1 & \\
\hline SSTR2 & 13 & 1 & 0 & 0 & 7.1 & \\
\hline SSTR3 & 11 & 2 & 1 & 0 & 21.4 & \\
\hline SSTR4 & 10 & 2 & 2 & 0 & 28.6 & \\
\hline SSTR5 & 6 & 4 & 3 & 1 & 64.3 & \\
\hline \multicolumn{7}{|c|}{ Eutopic endometrium } \\
\hline SSTR1 & 8 & 2 & 2 & 0 & 33.3 & $<0.001$ \\
\hline SSTR2 & 7 & 3 & 2 & 0 & 41.7 & $<0.001$ \\
\hline SSTR3 & 5 & 4 & 2 & 1 & 58.3 & $<0.001$ \\
\hline SSTR4 & 5 & 5 & 1 & 1 & 58.3 & $<0.001$ \\
\hline SSTR5 & 2 & 4 & 4 & 2 & 83.3 & 0.002 \\
\hline \multicolumn{7}{|c|}{ Ectopic endometrium } \\
\hline SSTR1 & 17 & 6 & 4 & 3 & 43.3 & $<0.001$ \\
\hline SSTR2 & 9 & 11 & 6 & 4 & 70.0 & $<0.001$ \\
\hline SSTR3 & 14 & 7 & 6 & 3 & 53.3 & $<0.001$ \\
\hline SSTR4 & 15 & 8 & 5 & 2 & 50.0 & 0.002 \\
\hline SSTR5 & 1 & 6 & 14 & 9 & 96.7 & $<0.001$ \\
\hline
\end{tabular}

${ }^{\mathrm{a}}$ Vs. control group. SSTR, somatostatin receptor.

A

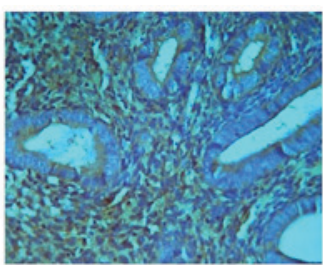

C

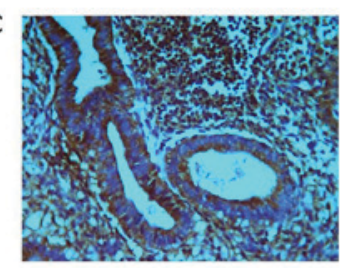

E

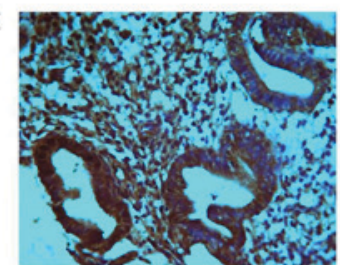

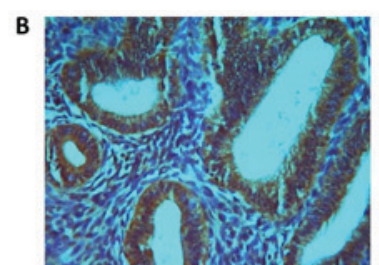

D

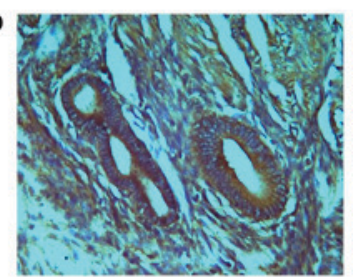

Figure 3. Expression of SSTR subtypes in eutopic endometrial tissues (magnification, x400). (A) SSTR1, (B) SSTR2, (C) SSTR3, (D) SSTR4 and (E) SSTR5. SSTR, somatostatin receptor.

including SSTR2, SSTR3 and SSTR5; ii) weaker affinity, with substrates including SSTR1 and SSTR4. SSTR1, SSTR2

A
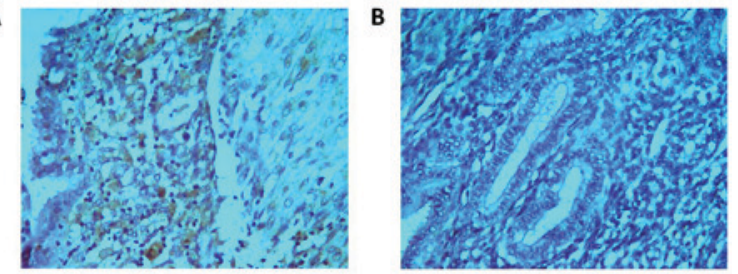

C
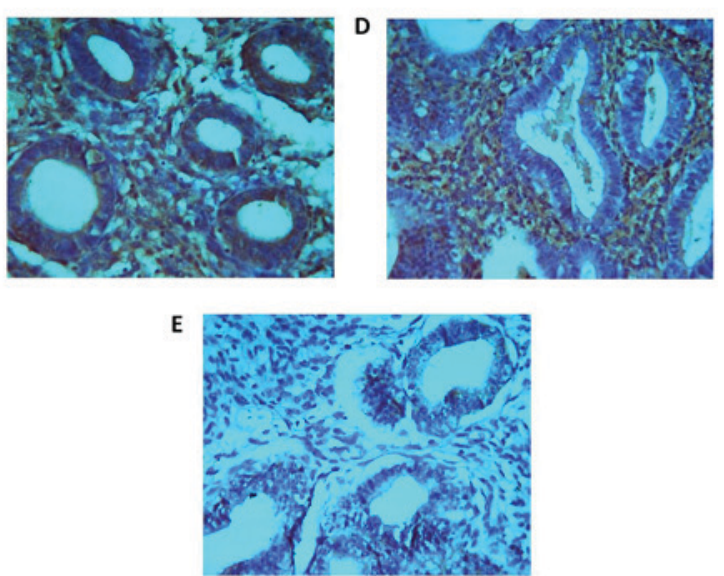

Figure 4. Expression of SSTR subtypes in normal endometrial tissues (magnification, x400). (A) SSTR1, (B) SSTR2, (C) SSTR3, (D) SSTR4 and (E) SSTR5. SSTR, somatostatin receptor.

and SSTR5 mainly mediate the anti-proliferative effect of SS. SSTR is distributed in all of the major human lymphoid 
organs, including thymus, spleen, lymph nodes, tonsils and gut-associated lymphoid tissues (33). SSTR, expressed as different subtypes in different lesion tissue types, occurs in a wide variety of neuroendocrine tumors and tumors of the nervous system; it is differentially expressed in human tumor and healthy tissues $(11,34)$. It has been reported that SSTR is also expressed in non-neuroendocrine tumor tissues; e.g., $>50 \%$ of breast cancer and $40 \%$ of colorectal cancer tissues were reported to be positive for SSTR $(35,36)$. SSTR is also expressed in liver, prostate and pancreatic cancers, as well as in gastric mucosa-associated lymphoid tissue lymphoma and its metastases (37-40). Schulz et al (41) detected the expression of SSTR1, -2 and -3 in 12 patients with cervical carcinoma and the positive rate was 38,57 and $43 \%$, respectively, while they were negative for the expression of SSTR4 and -5; furthermore, SSTR1-5 was expressed in 18 patients with endometrial carcinoma with positive rates of $32,39,43,4$ and $4 \%$, respectively.

Although a large number of studies have assessed SSTA and SSTR in other systems, studies have not focused on the expression of SSTR in EMS lesion tissues (35-40). Green et al (13) have assessed the expression of SSTR2 in the endometrium during the human menstrual cycle using the immunohistochemistry and RT-qPCR, and their results indicated that SSTR2 was expressed throughout the menstrual cycle. Fasciani et al (42) discovered that SSTR1, SSTR2 and SSTR5 were highly expressed in ovarian and peritoneal endometrial lesions using immunohistochemistry and RT-qPCR. Furthermore, a cell experiment indicated that the octreotide inhibits the migration and proliferation of endometrial cells (42). Annunziata et al (43) reported that SSTR1-5 were expressed in EMS tissues and cells, and that in normal eutopic endometrial cells, mainly SSTR1 was expressed, while the expression of STR 3 and -2 was low and SSTR4 and -5 were not expressed.

The immunohistochemical results of the present study indicated that SSTR1-5 were expressed in EMS tissues from 30 patients at the rates of 43.3, 70, 53.3, 50 and $96.7 \%$, respectively, which was significantly associated with the clinical stage of the patients. However, in previous results of Fasciani et al (42) and Annunziata et al (43), the expression of SSTR1-5 was not significantly associated with the clinical stage. It was hypothesized that the difference may be due to the different clinical samples and populations, which require more studies for confirmation. In the present study, the positive expression rate of SSTR1-5 in eutopic endometrium from 14 EMS patients was 33.3, 41.7, 58.3, 58.3 and $83.3 \%$, respectively, whilst that in normal endometrial tissue was lower than that in ectopic (43.3, 70.0, 53.3, 50.0 and 96.7\%) and eutopic endometrium at 7.1, 7.1, 21.4,28.6 and $64.3 \%$, respectively. The results verified that SSTR1-5 was expressed in the ectopic and eutopic endometrium groups and thus provides a therapeutic basis the use of SSTA for EMS.

The results of the present study indicated that the positive expression rate of SSTR 1-5 in EMS and eutopic endometrium cells was higher than that in normal endometrium, suggesting that a similarity between eutopic and EMS cells and a difference from normal endometrium, further confirming the 'eutopic endometrium determinism' theory. Therefore, the detection of SSTR expression in the eutopic endometrium is of clinical significance.
Various clinical studies have confirmed that the SSTA, including octreotide, has inhibitory effects on pancreatic cancer, breast cancer, neuroendocrine tumors and carcinoid tumors (4-6). Scintigraphy (SS receptor imaging, SS receptor scintigraphy) with radiolabeled SSTA has been used for diagnosing and locating tumors (44). Radiolabeled SS analogues bind to SSTR-positive tumors and help in making a definite diagnosis (45). Fasciani et al (42) injected ${ }^{111}$ In-diethylene triamine pentaacetic acid octreotide in 8 EMS patients pre-operatively, and when scanning was performed after $12 \mathrm{~h}$, stronger signals were detected in the pelvic cavity of 6 patients and weaker signals in that of 2 patients, and no adverse reactions were encountered. By scintigraphy using radiolabeled SSTA, EMS may be located and diagnosed, EMS lesions that B ultrasound and computed tomography cannot detect in the pelvic cavity and intestinal duct may be discovered and it is possible to make an auxiliary diagnosis for patients with EMS-induced chronic pelvic pain (46).

Previous studies have indicated that in certain types of cancer tissue with low or no expression of SSTR, including pancreatic, gastric, colorectal and ovarian cancer, the expression levels of SSTR may be improved by transfection of SSTR gene to thus improve the efficacy of SSTA $(47,48)$. For endometrial cells with low expression levels of SSTR, high expression of SSTR may be genetically induced (43), thus increasing the likelihood for the successful treatment of EMS using SSTA.

The present study indicated that SS and its receptor are expressed in EMS tissues or cells and enhanced the knowledge in the field, on which novel methods for the diagnosis and treatment of EMS using SSTR gene transfection and SSTA approaches may be based.

\section{Acknowledgements}

Not applicable.

\section{Funding}

No funding received.

\section{Availability of data and materials}

The analyzed data sets generated during the study are available from the corresponding author on reasonable request.

\section{Authors' contributions}

YaZ conducted the experiments and wrote the manuscript, LP and XL collected the data and performed the experiments, and YiZ designed the study. The final version of the manuscript has been read and approved by all authors, and each author believes that the manuscript represents honest work.

\section{Ethical approval and consent to participate}

The present study was approved by Ethics Committee of Xiangya Hospital of Central South University 
(Changsha, China) and informed consent was obtained from all subjects.

\section{Patient consent for publication}

Not applicable.

\section{Competing interests}

The authors declare that they have no competing interests.

\section{References}

1. Leyendecker G, Kunz G, Noe M, Herbertz M and Mall G: Endometriosis: A dysfunction and disease of the archimetra. Hum Reprod Update 4: 752-762, 2015.

2. Vercellini P, Viganò P, Somigliana E and Fedele L: Endometriosis: Pathogenesis and treatment. Nat Rev Endocrinol 10: 261-275, 2014.

3. Gaudillère A, Misery L, Bernard C, Souchier C, Claudy A and Schmitt D: Presence of somatostatin in normal human epidermis. Br J Dermatol 137: 376-380, 2015.

4. Modlin IM, Pavel M, Kidd M and Gustafsson BI: Review article: Somatostatin analogues in the treatment of gastroenteropancreatic neuroendocrine (carcinoid) tumours. Aliment Pharmacol Ther 31: 169-188, 2010.

5. Appetecchia M and Baldelli R: Somatostatin analogues in the treatment of gastroenteropancreatic neuroendocrine tumours, current aspects and new perspectives. J Exp Clin Cancer Res 29: 19, 2010.

6. Pollak MN and Schally AV: Mechanisms of antineoplastic action of somatostatin analogs. Proc Soc Exp Biol Med 217: 143-152, 1998.

7. Fanselow EE and Connors BW: The roles of somatostatin-expressing (GIN) and fast-spiking inhibitory interneurons in up-down states of mouse neocortex. J Neurophysiol 104: 596-606, 2010

8. Ludlam WH and Anthony L: Safety review: Dose optimization of somatostatin analogs in patients with acromegaly and neuroendocrine tumors. Adv Ther 28: 825-841, 2011.

9. Igarashi H, Hijioka M, Lee L and Ito T: Biotherapy of pancreatic neuroendocrine tumors using somatostatin analogs. J Hepatobiliary Pancreat Sci 22: 618-622, 2015.

10. Samimi M, Gardair C, Touze A, Coursagetb P, Kerdraond R, Estevee E, Crouef A, Avenel-Audrang M, Hainaulth E, Benetoni N, et al: Expression des récepteurs de la somatostatine (SSTR-2A et SSTR-5) et relation avec les données cliniques dans une cohorte de 99 patients avec carcinomes à cellules de Merkel Annales De Dermatologie Et De Venereologie 141: S242-S243, 2014.

11. Kaemmerer D, Schindler R, Mußbach F, Dahmen U, Altendorf-Hofmann A, Dirsch O, Sänger J, Schulz S and Lupp A: Somatostatin and CXCR4 chemokine receptor expression in hepatocellular and cholangiocellular carcinomas: Tumor capillaries as promising targets. BMC Cancer 17: 896, 2017.

12. Halmos G, Sun B, Schally AV, Hebert F and Nagy A: RAPID COMMUNICATION: Human ovarian cancers express somatostatin receptors. J Clin Endocrinol Metabol 85: 3509-3512, 2000.

13. Green VL, Richmond I, Maguiness S, Robinson J, Helboe L, Adams IP, Drummond NS and Atkin SL: Somatostatin receptor 2 expression in the human endometrium through the menstrual cycle. Clin Endocrinol (Oxf) 56: 609-614, 2002.

14. Boujenah J, Hugues JN, Sifer C, Bricou A, Cédrin-Durnerin I, Sonigo C, Monforte M and Poncelet C: Endometriosis fertility index, or classification of the american society of reproductive medicine for postoperative endometriosis patients with infertility: Which is more relevant? Gynecol Obstet Fertilite 43 806-809, 2015 (In French).

15. Livak KJ and Schmittgen TD: Analysis of relative gene expression data using real-time quantitative PCR and the 2(-Delta Delta C(T)) method. Methods 25: 402-408, 2001.

16. Szolcsányi J, Helyes Z, Oroszi G, Németh J and Pintér E: Release of somatostatin and its role in the mediation of the anti-inflammatory effect induced by antidromic stimulation of sensory fibres of rat sciatic nerve. Br J Pharmacol 123: 936-942, 2010.
17. Nilsson CL, Brinkmalm A, Minthon L, Blennow K and Ekman R: Processing of neuropeptide $\mathrm{Y}$, galanin and somatostatin in the cerebrospinal fluid of patients with Alzheimers disease and frontotemporal dementia. Peptides 22: 2105-2112, 2001.

18. Kang TC, Park SK, Do SG, Suh JG, Jo SM, Oh YS, Jeong YG and Won MH: The over-expression of somatostatin in gerbil entorhinal cortex induced by seizure. Brain Res 882: 55-61, 2000

19. Patel YC: Somtostat in and its receptor family. Front Neuroendocrinol 20: 157-198, 1999.

20. Sbracia M and Scarpellini F: PIF expression in endometriosis: Its possible role in inducing ectopic endometrium immune-privilege. J Reprod Immunol 122: 40, 2017. Ho HN, Wu MY and Yang YS: Peritoneal cellular immunity and endometriosis. Am J Reprod Immunol 38: 400-412, 2011.

21. Lang J: Further improve EMS basic and clinical research. Chin J Obstet Gynecol 36: 711-713, 2001 (In Chinese).

22. Scarborough DE, Lee SL, Dinarello CA and Reichlin S: Interleukin-1 beta stimulates somatostatin biosynthesis in primary cultures of fetal rat brain. Endocrinology 124: 549-551, 1989.

23. Dasgupta P: Somatostatin an alogues: Multiple roles incellular proliferation, neoplasia, andangiogenesis. Pharmacol Ther 102: 61-85, 2004.

24. Ma W, Liu B,Li Y,Huang ZJ, Zhang LI and Tao HW: Visual representations by cortical somatostatin inhibitory neurons-selective but with weak and delayed responses. J Neurosci 30: 14371-14379, 2010.

25. Reisine T and Bell GI: Molecular properties of somatostatin receptor. Neuroscience 67: 777-790, 1995.

26. Cordelier P, Estève JP, Bousquet C, Delesque N, O'Carroll AM, Schally AV, Vaysse N, Susini C and Buscail L: Characterization of the antiproliferative signal meditated by the somatostatin receptor subtype SSTR5. Proc Natl Acad Sci USA 94: 9343-9348, 1997.

27. Charland S, Boucher MJ, Houde M and Rivard N: Somatostatin inhibits Aktphosphorylation and cell cycle entry, but not $\mathrm{p} 42 / \mathrm{p}$ 44 mitogen activated protein(MAP)kinase activation in normal and tumoral pancreatic acinar cells. Endocrinology 142: 121-128, 2001.

28. Feooux G, Bousquet C, Cordelier P, Benali N, Lopez F, Rochaix P, Buscail L and Susini C: Signal transduction of somatostatin receptors negatively controlling cell proliferation. J Physiol Paris 94: 205-210, 2000.

29. Feuoux G, Lopez E, Esteve JP, Ferrand A, Vivier E, Vely F, Saint-Laurent N, Pradayrol L, Buscail L and Susini C: Critical role of Src and SHP-2 in sst2 somatostatin receptor-mediated activation of SHP-1 and inhibition of cell proliferation. Mol Biol Cell 14: 3911-3928, 2003.

30. Woltering EA: Development of targeted somatostatin-based antiangiogenic therapy: A review and future perspectives. Cancer Biother Radiopharm 18: 601-609, 2003.

31. Adams RL, Adams IP, Lindow SW, Zhong W and Atkin SL: Somatostatin receptors 2 and 5 are preferentially expressed in proliferating endothelium. Br J Cancer 92: 1493-1498, 2005.

32. Zhang Y, Cao H, Hu YY, Wang H and Zhang CJ: Inhibitory effect of curcumin on angiogenesis in ectopic endometrium of rats with experimental endometriosis. Int J Mol Med 27: 87-94, 2011.

33. Ferone D, Lombardi G and Colao A: Somatostatin receptors inimmune system cells. Minerva Endocrinol 26: 165-173, 2001 (In Italian).

34. Mehta S, de Reuver PR, Gill P, Andrici J, D'Urso L, Mittal A, Pavlakis N, Clarke S, Samra JS and Gill AJ: Somatostatin receptor SSTR-2a expression is a stronger predictor for survival Than Ki-67 in pancreatic neuroendocrine tumors. Medicine (Baltimore) 94: e1281, 2015.

35. Krenning EP, Kooij PP, Pauwels S, Breeman WA, Postema PT, De Herder WW, Valkema R and Kwekkeboom DJ: Somatostatin receptor: Scintigraphy and radionuclide therapy. Digestion 57 (Suppl 1): S57-S61, 1996.

36. van Eijck CH, Krenning EP, Bootsma A, Oei HY, van Pel R, Lindemans J, Jeekel J, Reubi JC and Lamberts SW: Somatostatin-receptor scintigraphy in primary breast cancer. Lancet 343: 640-643, 1994.

37. Reynaert H, Rombouts K, Vandermonde A, Urbain D, Kumar U, Bioulac-Sage P,Pinzani M, Rosenbaum J and Geerts A: Expression of somatostatin receptors in normal and cirrhotic human liver and in hepatocellular carcinoma. Gut 53: 1180-1189, 2004.

38. Hansson J, Bjartell A, Gadaleanu V, Dizeyi $\mathrm{N}$ and Abrahamsson PA: Expression of somatostatin receptor subtypes 2 and 4 in human benign prostatic hyperplasia and prostatic cancer. Prostate 53: 50-59, 2002. 
39. Li M, Li W, Kim HJ, Yao Q, Chen C and Fisher WE: Characterization of somatostatin receptor expression in human pancreatic cancer using real-time RT-PCR. J Surg Res 119: $130-137,2004$.

40. Raderer M, Traub T, Formanek M, Virgolini I, Osterreicher C, Fiebiger W, Penz M, Jäger U, Pont J, Chott A and Kurtaran A: Somatostatin-receptor scintigraphy for staging and follow-up of patients with extraintestinal marginal zone B-cell lymphoma of the mucosa associated lymphoid tissue(MALT)-type. $\mathrm{Br}$ J Cancer 85: 1462-1466, 2001.

41. Schulz S, Schmitt J and Weise W: Frequent expression of immunoreactive somatostatin receptors in cervical and endometrial cancer. Gynecol Oncol 89: 385-390, 2003.

42. Fasciani A, Quilici P,BiscaldiE,Flamini M, Fioravanti A, Orlandi P Oliviero J, Repetti F, Bandelloni R, Danesi R, et al: Overexpression and functional relevance of somatostatin receptor- $-1,-2$, and -5 in endometrium andendometrioticlesions.JClinEndocrinol Metab 95: 5315-5319, 2010.

43. Annunziata M, Luque RM, Durán-Prado M, Baragli A, Grande C Volante M, Gahete MD, Deltetto F, Camanni M, Ghigo E, et al: Somatostatin and somatostatin analogues reduce PDGF-induced endometrial cell proliferation and motility. Hum Reprod 27: 2117-2129, 2012.

44. Kumar S, Kumar Mishra A, Chhikara BS, Chuttani K and Kumar Sharma R: Preparation and pharmacological evaluation of a new radiopharmaceutical, technetium-99m-5-fluorouracil, for tumor scintigraphy. Hell J Nucl Med 11: 91-95, 2008.
45. Hasegawa S, Kobayashi N, Tokuhisa M, Goto A, Takano S, Takada Y, Kaneta T, Mori R, Matsuyama R, Endo I, et al: Clinical usefulness of somatostatin receptor scintigraphy in Japanese patients with gastroenteropancreatic neuroendocrine tumors. Digestion 96: 13, 2017.

46. Kennedy SH, Mojiminiyi OA, Soper N, Shepstone BJ and Barlow DH: Immunoscintigraphy of endometriosis. Br J Obstet Gynecol 97: 667-670, 2010.

47. Rochaix P, Delesque N, Estève JP, Saint-Laurent N, Voight JJ, Vaysse N, Susini C and Buscail L: Gene therapy for pancreatic carcinoma: Local and distant antittmaor effects after somatostatin receptor sst2 gene transfer. Human Gene Therapy 10: 995-1008, 1999.

48. Chaudhuri TR, Rogers BE, Buchsbaum DJ, Mountz JM and Zinn KR: A noninvasive receptor system to image Adenoviral-mediated gene transfer to ovarian cancer xenogragts. Gynecol Oncol 83: 432-438, 2001. Attribution-NonCommercial-NoDerivatives 4.0 International (CC BY-NC-ND 4.0) License. 